\title{
Abundance of Natural Enemies Associated with Rhopalosiphum maidis (Fitch) in Maize Based Planting Pattern
}

\author{
M.K. Tali, G. Chhangani, M.K. Mahla, A. Vyas and K.V.N. Reddy* \\ Department of Entomology, Rajasthan College of Agriculture, Maharana Pratap University of \\ Agriculture and Technology, Udaipur, Rajasthan-313001, India \\ *Corresponding author
}

A B S T R A C T

\begin{tabular}{|c|}
\hline Keywords \\
\hline $\begin{array}{l}\text { Natural enemies, } \\
\text { Coccinellids, } \\
\text { Syrphid fly, Maize, } \\
\text { Aphid, Intercrops }\end{array}$ \\
\hline Article Info \\
\hline $\begin{array}{l}\text { Accepted: } \\
\text { 17 July } 2018 \\
\text { Available Online: } \\
\text { 10 August } 2018\end{array}$ \\
\hline
\end{tabular}

The present investigation on Abundance of natural enemies associated with Rhopalosiphum maidis (Fitch) in maize based planting system was carried out at Instructional farm and Department of Entomology, Rajasthan College of Agriculture, MPUAT, Udaipur. Maize variety Pratap maize-5 was sown with different intercrops viz., green gram, black gram, cowpea and soyabean in kharif, 2017. The coccinellids appeared in first week of August and thereafter gradually increased with aphid population reaching to its peak in second week of September, 2017. The maximum seasonal mean population of coccinellids was recorded in maize + cowpea (5.09 aphids/ plant). The mean population of coccinellids had a significant positive correlation with mean atmospheric temperature in all the intercrop treatments. The predation of aphids by the larval population of syrphid fly maggots was observed from the first week of August, in the maize + greengram, maize + blackgram and maize + cowpea; while, in sole maize and maize + soybean the predation began in second week of August. The maximum seasonal mean population of syrphid fly maggots was recorded in maize + cowpea (2.00 maggots/ plant).

\section{Introduction}

Maize (Zea mays L.) belongs to family Poaceae and is one of the most versatile crop having high yield potential and wide adaptability. It is used as human food, animal feed, in starch industry, corn oil production and as baby corn (Singh, 2014). Its grain contains protein $(10 \%)$, oil (4\%), carbohydrates $(70 \%)$, fat (5 to $7 \%$ ), fiber (3 to $5 \%$ ) and minerals $(2 \%)$. Maize is cultivated on an area of 8.69 mha with a production of 21.80 million tonnes and productivity of $2509 \mathrm{~kg} / \mathrm{ha}$ (Anonymous,
2016). Rajasthan is one of the major maize growing states in India covering an area of 0.88 mha with a production of 1.14 million tonnes and productivity of $1318 \mathrm{~kg} /$ ha (Govt. of Rajasthan. 2016). Maize can be grown in both rabi and kharif seasons in Rajasthan, but it is a major kharif season crop in the maize growing districts. The area under rabi maize is increasing in Banswara and Dungarpur districts of the state where irrigation facilities are available. Among the cultural methods, inter and mixed cropping systems, the popular forms of crop-crop diversity, have become more popular in the rainfed regions. The 
interest to shift pest management strategies from the intensive use of agrochemicals to more sustainable and ecologically friendly practices has increased in recent years. One alternative to conventional farming system is the implementation of diversification that increases diversity in and around the field to increase the occurrence of natural enemies, reduce pest pressure and enhance crop production. The diversification practices (a) enhance natural enemies in 52 per cent, (b) reduce pest pressure in 53 per cent and (c) increase yield in only 32 per cent of the cases where this was examined (Poveda et al., 2008). Among the cultural methods, inter and mixed cropping systems, the popular forms of crop-crop diversity, have become more popular in the rainfed regions. Intercropping is one of the important cultural practices for pest management, which is based on the principle of reducing insect pests by increasing the diversity of an ecosystem (Letourneau and Altieri, 1983; Risch et al., 1983 and Baliddawa, 1985). Intercropping can affect the microclimate of the agro ecosystem and ultimately produce an unfavorable environment for pests.

\section{Materials and Methods}

The experiment to record the seasonal incidence of aphids was conducted in plots size of $3.0 \mathrm{~m} \times 5.0 \mathrm{~m}$ replicated four times with row to row and plant to plant spacing of $60 \mathrm{~cm}$ and $20 \mathrm{~cm}$, respectively. The insect pest complex infesting the maize crop was recorded from 21 days after germination till harvest of crop at weekly interval. The population of associated enemies in maize ecosystem was recorded and data obtained were using suitable statistical tools.

\section{Sampling techniques}

The associated natural enemies were recorded by the visual count technique from the 5 randomly selected plants per replication during early hours of the day. The numbers associated natural enemies were correlated with prevailing meteorological parameters using suitable statistical tools.

\section{Statistical analysis}

The abiotic factors viz., temperature, relative humidity and rainfall were recorded throughout the crop season and simple correlation with the population of associated natural enemies was workout using the method suggested by Karl Pearson.

$$
r_{x y}=\frac{\sum X Y-\frac{\sum X \sum Y}{n}}{\sqrt{\left[\sum X^{2}-\frac{\left(\sum X\right)^{2}}{n}\right]\left[\sum Y^{2}-\frac{\left(\sum Y\right)^{2}}{n}\right]}}
$$

Where,

$r_{x y}=$ Simple correlation coefficient.

$\mathrm{X}=$ Variable i.e. abiotic component.

(Average temperature, relative humidity and total rainfall)

$\mathrm{Y}=$ Variable i.e. mean number of aphid and their associated natural enemies per plant.

$\mathrm{n}=$ Number of observations.

The correlation coefficient (r) values will be subjected to the test of significance using ttest:

$$
\mathrm{t}=\frac{\mathrm{r}}{\sqrt{1-\mathrm{r}^{2}}} \times \sqrt{\mathrm{n}-2} \sim \mathrm{t}_{\mathrm{n}-2} \text { d.f. }
$$

The calculated t-value obtained will be compared with tabulated t-value at $1 \%$ and $5 \%$ level of significance. 


\section{Results and Discussion}

The occurrence of aphidiphagous coccinellid beetles during the course of study has been given in Table 1. The coccinellids appeared in first week of August and thereafter gradually increased till second week of September, 2017.

The respective mean values of coccinellids per plant in intercrop treatments were maize sole (5.80), maize + green gram (8.40), maize + black gram (10.00), maize + cowpea (10.80) and maize + soybean (6.00). The maximum seasonal mean population of coccinellids was recorded in maize + cowpea (5.09 aphids/ plant).

The mean population of coccinellids had a significant positive correlation with mean atmospheric temperature in all the intercrop treatments. The correlation coefficient values in the maize based planting patterns were as: sole maize $(\mathrm{r}=0.62)$, maize + greengram $(\mathrm{r}=0.61)$, maize + blackgram $(\mathrm{r}=0.61)$, maize + cowpea $(\mathrm{r}=0.69)$ and maize + soybean $(\mathrm{r}=0.62)$. The mean relative humidity and total rainfall did not influence the coccinellid population.

During the experimental period, the syrphid fly maggots population varied during the different weeks of observations under the sole $\&$ intercrop treatments (Table 2). The predation of aphids by the larval population of syrphid fly maggots was observed from the first week of August in the maize + green gram, maize + black gram and maize + cowpea; while, in sole maize and maize + soybean the predation began in first week of August, 2017. Their population gradually increased and reached to the maximum in second week of September, 2017 with mean values of $2.80,2.80,4.20,4.60$ and 1.80 maggots per plant in sole maize, maize + green gram, maize + black gram, maize + cowpea and maize + soybean, respectively.

The maximum seasonal mean of syrphid fly maggots was recorded in maize + cowpea (2.00 maggots/ plant), followed by that in maize + black gram (1.84 maggots/ plant), maize + green gram (1.33 maggots/ plant) and sole maize (0.96 maggots/ plant); whereas, the minimum syrphid fly maggots were recorded in maize + soybean (0.76 maggots/plant). The abiotic factors of the environment did not evince a significant influence on the syrphid fly population.

The mean population of syrphid fly maggots had a significant positive correlation with mean atmospheric temperature in the treatments maize + green gram $(\mathrm{r}=0.61)$ and maize + cowpea $(r=0.67)$. The syrphid fly population under maize + black gram $(r=0.61)$ showed a significant positive correlation with mean relative humidity.

\section{Treatments details}

\begin{tabular}{|c|c|}
\hline S. No. & Treatment \\
\hline $\mathbf{T}_{\mathbf{1}}$ & Maize sole \\
\hline $\mathbf{T}_{\mathbf{2}}$ & Maize +Greengram $(1: 1)$ \\
\hline $\mathbf{T}_{\mathbf{3}}$ & Maize +Blackgram $(1: 1)$ \\
\hline $\mathbf{T}_{\mathbf{4}}$ & Maize +Cowpea $(1: 1)$ \\
\hline $\mathbf{T}_{\mathbf{5}}$ & Maize +Soybean $(1: 1)$ \\
\hline
\end{tabular}


Table.1 Occurrence of coccinellids on maize aphids in sole and intercropped maize during kharif, 2017

\begin{tabular}{|c|c|c|c|c|c|c|c|c|}
\hline \multirow{2}{*}{$\begin{array}{c}\text { Dates of } \\
\text { observation }\end{array}$} & \multirow{2}{*}{$\begin{array}{l}\text { Mean Atm. } \\
\text { Temp. }\left({ }^{\circ} \mathbf{C}\right)\end{array}$} & \multirow{2}{*}{$\begin{array}{l}\text { Mean RH. } \\
(\%)\end{array}$} & \multirow{2}{*}{$\begin{array}{c}\text { Total } \\
\text { Rainfall } \\
\text { (mm) }\end{array}$} & \multicolumn{5}{|c|}{ Mean No. of coccinellids /plant } \\
\hline & & & & $\mathbf{M}$ & $\mathbf{M}+\mathbf{G g}$ & $\mathrm{M}+\mathrm{Bg}$ & $\mathbf{M}+\mathbf{C}$ & $\mathbf{M}+\mathbf{S}$ \\
\hline 07 - Aug & 25.70 & 87.80 & 0.00 & 0.80 & 1.00 & 1.80 & 4.00 & 0.60 \\
\hline 14 - Aug & 26.40 & 85.40 & 2.80 & 2.00 & 4.00 & 3.80 & 4.00 & 1.80 \\
\hline 21 - Aug & 27.00 & 69.80 & 4.20 & 2.80 & 6.00 & 6.80 & 5.20 & 2.60 \\
\hline 28-Aug & 27.40 & 82.10 & 107.20 & 5.20 & 6.40 & 8.00 & 8.80 & 5.80 \\
\hline 04-Sept & 25.40 & 85.70 & 71.80 & 0.40 & 1.20 & 2.40 & 6.80 & 0.20 \\
\hline $11-$ Sept & 26.10 & 73.90 & 0.00 & 5.80 & 8.40 & 10.00 & 10.80 & 6.00 \\
\hline $18-$ Sept & 26.20 & 83.90 & 38.60 & 1.20 & 3.00 & 8.00 & 9.80 & 0.80 \\
\hline 25-Sept & 26.60 & 62.60 & 0.00 & 4.60 & 4.60 & 6.00 & 3.00 & 4.40 \\
\hline $02-$ Oct & 27.00 & 54.30 & 0.00 & 3.00 & 3.80 & 6.20 & 2.00 & 2.80 \\
\hline 09-Oct & 26.60 & 43.80 & 0.00 & 2.40 & 2.80 & 2.20 & 1.00 & 2.20 \\
\hline 16-Oct & 25.00 & 45.00 & 0.00 & 1.00 & 1.60 & 0.40 & 0.60 & 0.80 \\
\hline $\begin{array}{l}\text { Seasonal } \\
\text { Mean }\end{array}$ & 26.31 & 70.39 & 20.42 & 2.65 & 3.89 & 5.05 & 5.09 & 2.55 \\
\hline \multicolumn{4}{|c|}{$\begin{array}{l}\text { Coefficient of correlation ( } \mathbf{r}) \mathrm{b} / \mathrm{w} \text { coccinellids and mean } \\
\text { Atm. Temp. }\end{array}$} & $0.62 *$ & $0.61 *$ & $0.61 *$ & $0.69 *$ & $0.62 *$ \\
\hline \multicolumn{4}{|c|}{ Coefficient of correlation $(r) b / w$ coccinellids and mean $R H$} & -0.09 & 0.06 & 0.28 & 0.54 & -0.06 \\
\hline \multicolumn{4}{|c|}{$\begin{array}{l}\text { Coefficient of correlation (r) b/w coccinellids and Total } \\
\text { Rainfall }\end{array}$} & 0.08 & 0.06 & 0.21 & 0.35 & 0.15 \\
\hline
\end{tabular}

* Significant at $5 \%$ level of significance

Legend: $\mathrm{M}=$ Maize sole, $\mathrm{M}+\mathrm{Gg}=$ Maize + Geengram (1:1), M + Bg = Maize + Blackgram (1:1), M + C= Maize + Cowpea $(1: 1), \mathrm{M}+\mathrm{S}=\mathrm{Maize}+$ Soybean $(1: 1)$ 
Table.2 Occurrence of syrphid flies maggots on maize aphids in sole and intercropped maize during kharif, 2017

\begin{tabular}{|c|c|c|c|c|c|c|c|c|}
\hline \multirow{2}{*}{$\begin{array}{l}\text { Dates of } \\
\text { observation }\end{array}$} & \multirow{2}{*}{$\begin{array}{l}\text { Mean Atm. } \\
\text { Temp. }\left({ }^{\circ} \mathbf{C}\right)\end{array}$} & \multirow{2}{*}{$\begin{array}{l}\text { Mean RH. } \\
(\%)\end{array}$} & \multirow{2}{*}{$\begin{array}{c}\text { Total } \\
\text { Rainfall (mm) }\end{array}$} & \multicolumn{5}{|c|}{ Mean No. of syrphid flies maggots /plant } \\
\hline & & & & $\mathbf{M}$ & $\mathbf{M}+\mathbf{G g}$ & $\mathbf{M}+\mathbf{B g}$ & $\mathbf{M}+\mathbf{C}$ & $\mathbf{M}+\mathbf{S}$ \\
\hline 07 - Aug & 25.70 & 87.80 & 0.00 & 0.00 & 0.20 & 0.60 & 1.00 & 0.00 \\
\hline 14-Aug & 26.40 & 85.40 & 2.80 & 0.20 & 0.60 & 3.40 & 3.80 & 0.40 \\
\hline $21-$ Aug & 27.00 & 69.80 & 4.20 & 0.80 & 0.80 & 3.00 & 0.60 & 1.00 \\
\hline 28-Aug & 27.40 & 82.10 & 107.20 & 1.60 & 2.40 & 2.20 & 3.60 & 0.80 \\
\hline 04-Sept & 25.40 & 85.70 & 71.80 & 1.00 & 0.40 & 2.60 & 3.00 & 1.00 \\
\hline $11-$ Sept & 26.10 & 73.90 & 0.00 & 2.80 & 2.80 & 4.20 & 4.60 & 1.80 \\
\hline $18-$ Sept & 26.20 & 83.90 & 38.60 & 0.40 & 1.00 & 2.20 & 2.60 & 0.60 \\
\hline 25-Sept & 26.60 & 62.60 & 0.00 & 1.20 & 2.60 & 1.00 & 1.40 & 1.00 \\
\hline $02-$ Oct & 27.00 & 54.30 & 0.00 & 0.80 & 2.00 & 0.40 & 0.80 & 0.80 \\
\hline 09- Oct & 26.60 & 43.80 & 0.00 & 0.80 & 1.60 & 0.20 & 0.40 & 0.40 \\
\hline 16-Oct & 25.00 & 45.00 & 0.00 & 1.00 & 0.20 & 0.40 & 0.20 & 0.60 \\
\hline $\begin{array}{l}\text { Seasonal } \\
\text { Mean }\end{array}$ & 26.31 & 70.39 & 20.42 & 0.96 & 1.33 & 1.84 & 2.00 & 0.76 \\
\hline \multicolumn{4}{|c|}{$\begin{array}{l}\text { Coefficient of correlation ( } r \text { ) b/w syrphid flies maggots and } \\
\text { mean Atm. Temp. }\end{array}$} & 0.11 & $0.61 *$ & 0.10 & $0.67 *$ & 0.13 \\
\hline \multicolumn{4}{|c|}{$\begin{array}{l}\text { Coefficient of correlation (r) b/w syrphid flies maggots and } \\
\text { mean RH }\end{array}$} & -0.14 & -0.19 & $0.61 *$ & 0.46 & -0.03 \\
\hline \multicolumn{4}{|c|}{$\begin{array}{l}\text { Coefficient of correlation ( } \mathbf{r} \text { ) b/w syrphid flies maggots and } \\
\text { Total Rainfall }\end{array}$} & 0.17 & 0.09 & 0.23 & 0.47 & 0.09 \\
\hline
\end{tabular}

* Significant at $5 \%$ level of significance

Legend: $\mathrm{M}=$ Maize sole, $\mathrm{M}+\mathrm{Gg}=$ Maize + Geengram (1:1), $\mathrm{M}+\mathrm{Bg}=$ Maize + Blackgram (1:1), $\mathrm{M}+\mathrm{C}=$ Maize + Cowpea $(1: 1), \mathrm{M}+\mathrm{S}=\mathrm{Maize}+$ Soybean $(1: 1)$ 
As reviews on effect of intercropping on natural enemies in maize are scanty, the available literature on intercropping with different crops has been compared for discussion. The intercrops facilitated the natural proliferation of predators and recorded higher populations of coccinellids and spiders. Srinivasa Rao et al., (2004) reported the increased activity of coccinellids and spiders in leguminous intercrops. The low incidence of insect pests in intercrop systems was often attributed to one factor (i.e., higher abundance) of their parasitoids and predators, which supports the "natural enemies hypothesis". Kiran Kumar et al., (2008) reported that introducing fodder cowpea as an intercrop in paired rows of corn was significant in realising higher cob yield. Paired row of maize with 2 rows of black gram (2:2) was noticed to be productive intercropping row ratio (Naveena et al., 2012). Avil Kumar et al., (2003) observed that maize and soybean in 1:1 ratio was profitable. Components of intercropping system suffer significantly less damage from insects compared to their cultivation as a sole crops (Altieri \& Letourneau, 1999), which has positive impact on yield (Sarker et al., 2007).

\section{Acknowledgment}

The authors sincerely thank the Head, Department of Entomology, Dean, Rajasthan College of Agriculture and Director Research, MPUAT, Udaipur for providing the necessary facilities to conduct the research.

\section{References}

Anonymous, 2016. Directorate of economics and statistics, Department of Agriculture and Cooperation, Ministry of Agriculture, Goverment of India.

Anonymous, 2016. Vital Agriculture Statistics, Statistics Cell, Directorate of
Agriculture, Pant Krishi Bhawan, Jaipur. Govt. of Rajasthan p.47.

Atiyeh, R., Aslam, M and Baalbaki, R. 1996. Nitrogen fertilizer and planting date effects on insect pest populations of sweet corn. Pakistan J. Zoo., 28:163167.

Avil Kumar, K., Reddy, M.D., Sivasankar, A and Reddy, N.V. 2003. Yield and economics of maize (Zea mays) and Soybean (Glycine max) in intercropping under different row proportions. Indian J. Agri. Sci., 73: 69-71.

Baliddawa, C.W. 1985. Plant species diversity and crop pest control - an analytical review. Insect Sci. App., 6: 479-487.

Kiran kumar, T., Venkateswarulu, B., Prasad, P.V.N., Prasad P.R.K and Veeraraghavaiah, R. 2008. Growth and yield of Zea mays as influenced by intercropping with fodders. The Andhra Agri. J., 4: 417-421.

Letourneau, D.K and Altieri, M.A. 1983. Abundance patterns of a predator, Orius tristicolor (Hemiptera: Anthocoridae) and its prey, Frankliniella occidentalis (Thysanoptera: Thripidae): habitat attraction in polycultures versus monocultures. Environ. Ento., 12: 14641469.

Naveena, K., Mallikarjuna, G.B., Arunkumar M and Jayadeva H. M. 2012. Response surface methodology for evaluation of intercropping system of maize (Zea mays L.) and Urdgram (Vigna mungo). Mysore J. Agri. Sci. 46: 489-494.

Poveda K., Maria I.G., and Eliana M., 2008. Diversification practices, their effect on pest regulation and production. Revista Colombiana Entomologia, 34:2.

Risch, S.J., Andow, D. and Altieri M.A. 1983. Agro-ecosystem diversity and pest control: data, tentative conclusions, and new direction. Environ. Ento.,, 12: 625629. 
Sarker, P.K., Rahman, M.M. and Das, B.C. 2007. Effect of intercropping with ustard with onion and garlic on aphid population and yield. J. Bio-Sci., 15: 3540.

Singh, A.D. 2014. Maize in India. India Maize Summit. FICCI, pp 2.
Srinivasa Rao, M., Dharma Reddy, K and Singh, T.V.K. 2004. Impact of intercropping on the incidence of Maruca vitrata Geyer and Helicoverpa armigera Hubner and their predators on Pigeonpea during rainy and post rainy seasons, Shashpa, 11: 61-70.

\section{How to cite this article:}

Tali, M.K., G. Chhangani, M.K. Mahla, A. Vyas and Reddy, K.V.N. 2018. Abundance of Natural Enemies Associated with Rhopalosiphum maidis (Fitch) in Maize Based Planting Pattern. Int.J.Curr.Microbiol.App.Sci. 7(08): 2989-2995.

doi: https://doi.org/10.20546/ijcmas.2018.708.317 